\title{
Hydrodynamic modelling of potential impacts of climate change on hydrological connectivity of floodplain wetland
}

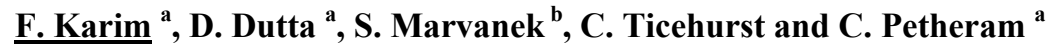 \\ ${ }^{a}$ CSIRO Land and Water, Christian Laboratory, Canberra, ACT 2601; Australia \\ ${ }^{b}$ CSIRO Land and Water, Glen Osmond, South Australia 2601; Australia \\ Email:fazlul.karimt@,csiro.au
}

\begin{abstract}
Hydrological connectivity between wetlands and the main streams is a major determinant of the ecological condition of floodplain systems. This paper describes the application of MIKE 21 hydrodynamic (HD) modelling tool to assess the hydrological connectivity between floodplain wetlands and main rivers in the Flinders catchment in north Queensland, Australia. The SRTM (Shuttle Radar Topography Mission) derived $30 \mathrm{~m}$ DEM was used to reproduce floodplain topography and stream networks in the HD model. Land surface roughness parameters were estimated using a land use map derived from remotely sensed data. The model was calibrated using stream gauge records (stage heights) on the floodplain and inundation maps derived from a combination of MODIS imagery. An algorithm was developed to combine the HD model results with floodplain topology to quantify flood inundation and connectivity between wetlands and rivers. The connectivity of 18 off-stream wetlands, which are considered ecologically important to fish population, was quantified for 3 different floods. The impacts of climate change on connectivity to individual wetland were assessed for Cdry (dry climate), Cwet (wet climate) and SLR (sea level rise) conditions. The results reveal that connectivity will decrease under dry climate and increase under wet climate while impact of SLR is minimal. The information could be useful to future studies on movement and recruitment patterns of aquatic biota during floods.
\end{abstract}

Keywords: Hydrological connectivity, wetland, hydrodynamic modelling, MODIS, ecology 


\section{INTRODUCTION}

Ecological value of floodplain wetlands depends on many factors, but a key determinant is how the wetlands are hydrologically connected to main river channels over time (Junk et al., 1989). Floods provide an opportunity for off-stream wetlands to be connected to main river channels by overbank flows. The high biodiversity found in many floodplains across the world are thought to be largely dependent upon 'flood pulses'. The Flinders is one of the Australia's largest unregulated river basins and it supports a large number of off-stream wetlands of distinct ecological value to fish population (Kennard, 2011). An important issue for the management of these wetlands especially under changing climate is to know the extent, timing and duration of their connectivity to maintain or even enhance connectivity and biophysical exchanges between the wetlands and rivers. This information is scarce for the majority of Australian floodplains since field based monitoring of connectivity for numerous individual wetlands is both difficult and time consuming. Previous studies have used a combination of remotely sensed inundated area and modelled discharge to predict how inundated area changes with perturbations to streamflow (e.g. Frazier and Page, 2006). The same approach has also been used to quantify how the number of inundated wetlands changes with river flow (Shaikh et al., 2001). However, these approaches are not dynamic and only provide information on potential wetland inundation when flow does not change rapidly (due to the time difference between when the remote sensing images can be obtained and the peak of inundation). It is also not possible for these approaches to properly define the duration of wetland connectivity, which can have an important influence on wetland ecology. In this study we used a two-dimensional (2D) hydrodynamic (HD) model to simulate the time history of inundation across the Flinders floodplain. The algorithm developed by Karim et al. (2012) was used to combine the HD model outputs with the floodplain topography to quantify the overbank inundation and connectivity between the wetlands and rivers.

\section{STUDY AREA AND DATA}

\subsection{Flinders Catchment}

The Flinders River catchment is located in northwest Queensland with a drainage area of approximately $109,000 \mathrm{~km}^{2}$ (Figure 1). The Flinders River, the longest of the Gulf Rivers, rises in the Great Dividing Range north-east of Hughenden, nearly 1,000 km from its entry to the Gulf of Carpentaria. It consists of several large tributaries including Dugald, Corella, Cloncurry, Gilliat and Saxby rivers. The catchment has a semi-arid tropical climate with large inter-annual variability in rainfall and stream flow. It has an average annual rainfall of $454 \mathrm{~mm}$ of which about $80 \%$ occurs during the wet season from December to March. Streamflow in this catchment is highly variable and seasonal, approximately $96 \%$ of runoff occurs during the wet season, with the majority of runoff occurring during the months January to March. Approximately $90 \%$ of the variance in the historical monthly time series of rainfall was within year variability and the remaining $10 \%$ was the inter-annual variability (Petheram and Yang, 2013). Flooding during summer and

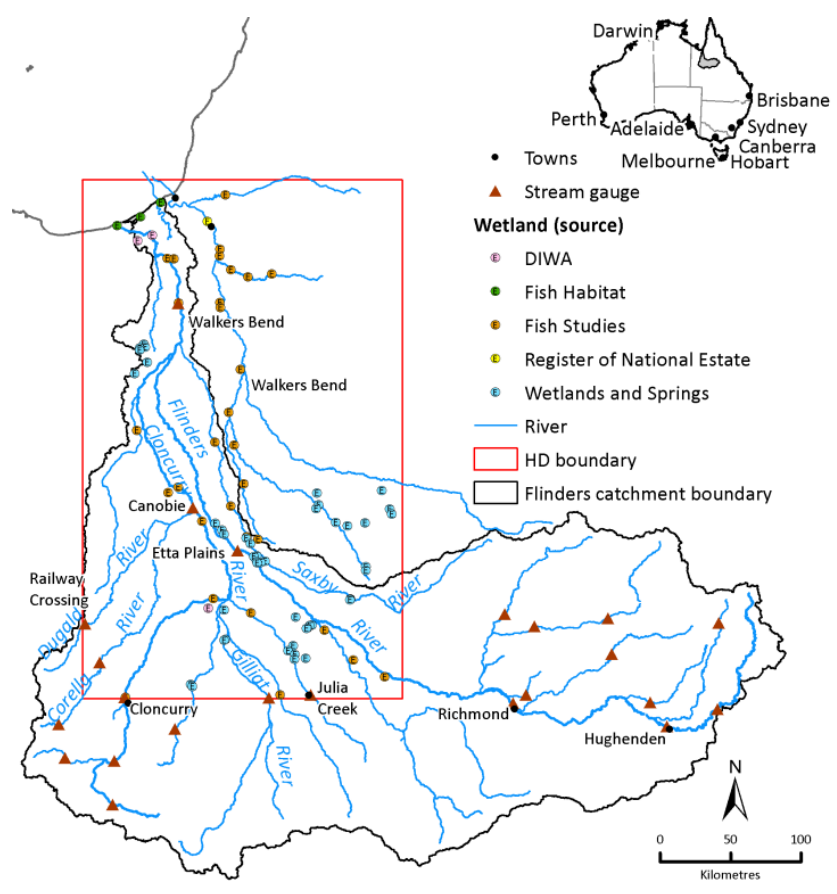

Figure 1. Flinders catchment and HD modelling domain showing floodplain rivers and wetlands (inset: location cessation of flows during the rest of the year are common characteristics of most of these streams. During the flooding events, the Flinders River as well as major tributaries can swell to inundate several kilometres across the floodplain (Dutta et al., 2013).

There are many nationally and internationally recognized water assets including wetlands located all across the floodplain (e.g. Lignum swamp, Southern Gulf, Stranded Fish Lake) and listed in the directory of important wetlands in Australia (Environment Australia, 2001). Wetlands in this region are also important because they bear historical significance or have high cultural value, particularly to Indigenous people. 


\subsection{Topography and land use}

SRTM derived 30-m resolution digital elevation model (DEM) was used to reproduce floodplain topography and stream networks in MIKE21 two-dimensional HD model. The watercourse lines in the topographic mapping "Hydrography feature dataset" from Australian Hydrological Geospatial Fabric (AHGF) and Google Earth Pro imagery were used to identify the significant stream networks, which were hydrologically corrected in the DEM by enforcing continuous flow paths from upstream to estuary using the streamnetwork. Using this DEM, computational grids in the HD model domain were generated by re-sampling the DEM into $150 \mathrm{~m}$ grids to keep the computational time within a reasonable limit (approx. 3 days of computer time for a flood of 20 days). An algorithm was used to ensure minimum elevation as seen in stream grids in the original $30 \mathrm{~m}$ DEM also represented in the $150 \mathrm{~m}$ grid.

Hydraulic roughness of the land surface was derived using a Geoscience Australia's dynamic land cover map and was represented in the model using Manning's roughness coefficient $(n)$. The land use was categorized into streams, agriculture, riparian vegetation, trees, bare soil, wetlands, savanna, and then converted to a roughness map by substituting the land use code with a corresponding roughness coefficient. Initial roughness coefficients were estimated based on published literature and then refined as a part of the calibration process.

\subsection{Streamflow and tide data}

Mean daily discharge and stage height data were obtained from the Department of Environment and Resources Management (DERM), Queensland Government for the 6 floodplain gauging stations (Walker Bend, Etta Plains, Canobie, Railway Crossing, Cloncurry, Julia creek). Data period varied between stations with an average of 40 years. Data from Railway Crossing, Cloncurry and Julia Creek stations were used to define the upstream boundary conditions of the HD model. If a gauging station was not available at the model boundary, the simulated stream flow by a calibrated rainfall-runoff model was used (Petheram and Yang, 2013). Data from Walker Bend, Etta Plains and Canobie were used to calibrate the HD model.

Tide data were used to specify the downstream boundary conditions at the end of the streams and floodplains that are connected to sea. Tide data of 10-minute resolution at Karumba obtained from the Maritime Safety Unit of Queensland Government was used as the downstream boundary condition.

\subsection{Wetlands}

The floodplain wetlands were identified using a combination of data sources. These included the directory of important wetlands in Australia (DIWA, Environment Australia, 2001), registers of national estates and wetlands (Department of Sustainability, Environment, Water, Population and Communities), fish habitat area (Department of Agriculture, Fishers and Forestry, Queensland Government), dynamic land cover maps (Geoscience Australia) and 1:250,000 topographic maps. Based on these sources, 119 water assets were identified including wetlands, bores and springs in the Flinders floodplain and adjoining areas (e.g. part of Norman catchment). Given the very large number of water assets in the Flinders, we selected 18 off-stream wetlands with distinct ecological values, which are located across the floodplain ranging from less than a kilometre to $10 \mathrm{~km}$ from the Flinders River or its major tributary. The details of the wetland identification process and the physical and ecological properties of the wetlands can be found in Dutta et al. (2013).

\section{METHOD OF STUDY}

\subsection{Hydrodynamic modelling}

The MIKE 21 HD model was used to simulate inundation and flow connection between water bodies. The model was configured for the mid and lower parts of the Flinders and Norman catchments, which comprise the majority of off-stream wetlands in this region (Figure 1). The floodplains of Flinders and Norman Rivers often connect together during floods and floodwater crosses over from the Norman catchment to the Flinders creating a large single water body. There were 11 inflow boundaries contributing flow to the floodplain from the upper catchments. The upstream boundaries of the model were set well above the floodplain boundary to capture and define the upper catchment flows to the floodplain. Gauged flow data were available at 3 of these inflow boundaries (Cloncurry River at Cloncurry, Julia Creek at Julia Creek and Dugald River at Railway crossing), which were used as the boundary inflows. The missing data points in the gauged records were filled in using the simulated flow by the Flinders River System model (Lerat et al., 2013). For the remaining boundaries, the simulated runoff time series by a calibrated rainfall-runoff model (Petheram and Yang, 2013) were used. 
Runoff within the model domain was simulated using the Sacramento rainfall-runoff model (Petheram and Yang, 2013). Gridded runoff simulation was performed between 1 July 1890 and 30 June 2011 for 5-km resolution grids using the daily SILO gridded climate data. Morton areal wet potential evaporation was used to compute potential evaporation. The calibrated parameters from the most downstream gauge (Walkers Bend) were used for gridded simulation of runoff for the HD modelling. There were 196 sub-catchments in the HD model domain each having its own outlet derived from the DEM. The simulated gridded runoff was averaged to subcatchment runoff by assigning SILO cells to the subcatchments based on the intersecting cells. Averaged runoff was incorporated into the HD model as a point source at the outlet of each subcatchment. Sub-catchment boundaries and pour points were generated using $30 \mathrm{~m}$ grid SRTM data from arbitrarily located pour points, typically located at the stream junctions/inflow to main rivers. Runoff from upper catchments were obtained from stream gauge records (where available) and added as inflow boundary to the model.

The spatial resolution of the model was $150 \mathrm{~m}$ and the modelling domain consisted of approximately 3.7 million grid cells $(1509 \times 2427)$ covering an area of $82,500 \mathrm{~km}^{2}$. The computational time step was derived after satisfying numerical stability criteria. The model took about 4 days of computer time to simulate a flood of 30 days. At the inflow boundaries, daily time step discharges were specified. The model uses an inbuilt interpolation technique to derive streamflow at each computational time step. An initial water level map was generated by running the model on dry land for a constant inflow. Initial discharges at all computational grid cells were specified as zero. To avoid any effects of initial conditions, simulations for the first six hours were excluded from analyses and interpretations of the results. Model outputs include water surface elevation, depth, velocity and flow flux for each computational grid cell. Simulated outputs can be saved at the computational time step or a desired time step, which is a multiple of the computational time step (6-hour time step was used here). To assess how connectivity changes with flood magnitude (peak discharge and duration) we investigated one small flood (e.g. $2001, Q_{\max }=3612 \mathrm{~m}^{3} / \mathrm{s}, 21$ days) and one large flood (e.g. 2009, $Q_{\max }=5828 \mathrm{~m}^{3} / \mathrm{s}, 55$ days).

The flood maps derived from the daily MODIS imagery were used to calibrated the HD model along with the observed river stage data.. Flood events for the model calibration and post-audit were selected on the basis of the availability of the observed stage height data at the 3 gauging stations within modelling domain (Canobie on Cloncurry River, Etta Plains on Flinders River and Walkers Bend on Flinders River) and the availability of cloud free MODIS. The model was calibrated for the large flood event in 2009 and post-audited for the flood events in 2001. The flood maps derived from MODIS imagery using Open Water Likelihood (OWL) algorithm were used to compare spatial metrics of inundation area across the floodplain. The MODIS flood maps, originally produced as percentage of water within each pixel, were converted into a water mask where pixels with at least $1 \%, 5 \%$ and $10 \%$ water in them were compared to the simulated results. In addition, the gauged water heights at key locations (e.g., Canobie, Etta Plains and Walkers Bend) were used to compare the stage heights and time of peak arrival. During the manual calibration process, the floodplain topography was modified at the locations having steep land slopes to ensure the model stability. A slight adjustment was also made at the interface between the river and floodplain. The grid cells that represented streams were carefully checked and manually edited to ensure continuous stream channel. The final calibration was made by changing the roughness coefficient (Manning's $n$ ). During the calibration process roughness coefficients were varied iteratively for the major land uses (e.g. streams, Savanna, riparian vegetation) within the recommended range to attain a close agreement between the observed and simulated water depths and time of peak arrival at different locations on the floodplain.

\subsection{Estimating connectivity between wetland and river}

Connectivity between a wetland with the major rivers was considered through floodplain flows (i.e., overbank flooding). Connection and disconnection during overbank flooding were computed by identifying contiguous flow paths at every 6-hr time step for a threshold water depth of $30 \mathrm{~cm}$ following this was used in similar study by Karim et al. (2012). The estimation of connection time of a particular wetland to the river system was based on time series water depths derived from the 2D HD model at six-hourly time steps. To do this, an algorithm was developed to uniquely identify areas of contiguous water during each time step, by tagging all water bodies and river sections which were contiguous in that time step. The same procedures were repeated for all time steps and the results were accumulated to obtain the temporal sequence of connection and disconnection. Detail of analysis technique is available in Karim et al. (2012). Majority of the wetlands in the Flinders floodplain (except in the coastal plains) are small in size and were considered as "point" wetlands for connectivity analysis. These were reproduced in HD model by a single grid cell $(150 \times$ $150 \mathrm{~m}$ ). Polygon wetlands (mostly DIWA) were represented by model grids that approximately encompass the areal boundary of a wetland. 


\subsection{Assessing climate impact on connectivity}

Petheram et al. (2013) used 15 GCMs to study the impact of climate change on rainfall and other climate variables in the Flinders catchment. It was reported that approximately half the GCMs were found to result in a spatially averaged increase in mean annual rainfall (by up to $17 \%$ ) and half resulted in a decrease (by up to $33 \%$ ), relative to the historical climate. The potential changes in rainfall in the future will have impact on the streamflow and local runoff, which in turn, is likely to affect the flooding characteristics in the floodplains. The calibrated HD model was used to undertake scenario modelling to analyse the impacts of future climate on floodplain inundation and changes in wetland connectivity. The climate scenarios include Cdry (dry climate), Cwet (wet climate) and SLR (sea level rise). Two historical flood events of different magnitudes (2001 and 2009) were selected as the base-line events. The Sacramento rainfall-runoff model was used to simulate local runoff under future climate using empirically scaled rainfall data from 15 GCMs. The runoff results were ranked in order of increasing catchment average mean annual runoff. The GCM's corresponding to the $10^{\text {th }}$ and $90^{\text {th }}$ catchment average mean annual runoff were selected for the Cwet and Cdry climates respectively.

Based on available literature, the projected rise of mean sea level was considered as $80 \mathrm{~cm}$ for the worst case scenario in 2070. This was incorporated into the HD model by raising the observed daily tidal data at Karumba by $80 \mathrm{~cm}$. The other input data and boundary conditions in the calibrated model remained fixed. The calibrated HD model was run for the 2001 and 2009 flood events using the updated downstream boundary condition incorporating the projected SLR. The connectivity results for projected climates and SLR were obtained using same approach as described above.

\section{RESULTS AND DISCUSSION}

\subsection{Inundation}

Figure 2 presents the simulated inundation extents and the flood maps derived from MODIS imagery using the OWL algorithm with a $10 \%$ threshold during the 2009 flood. The days were selected based on the availability of MODIS images not obscured by cloud. The 2009 flood event in the Flinders catchment had the highest number of unobstructed MODIS images. It can be seen that the overall pattern of the simulated inundation extent in different parts of the Flinders floodplain is similar to the MODIS flood maps. The inundation maps from the HD model shows numerous thin lines of the channelized flow paths that are not seen on MODIS map. This is mainly due to the resolution of the MODIS imagery, which was $500 \mathrm{~m}$ compared to the $150 \mathrm{~m}$ resolution of the HD model. The matching between simulated
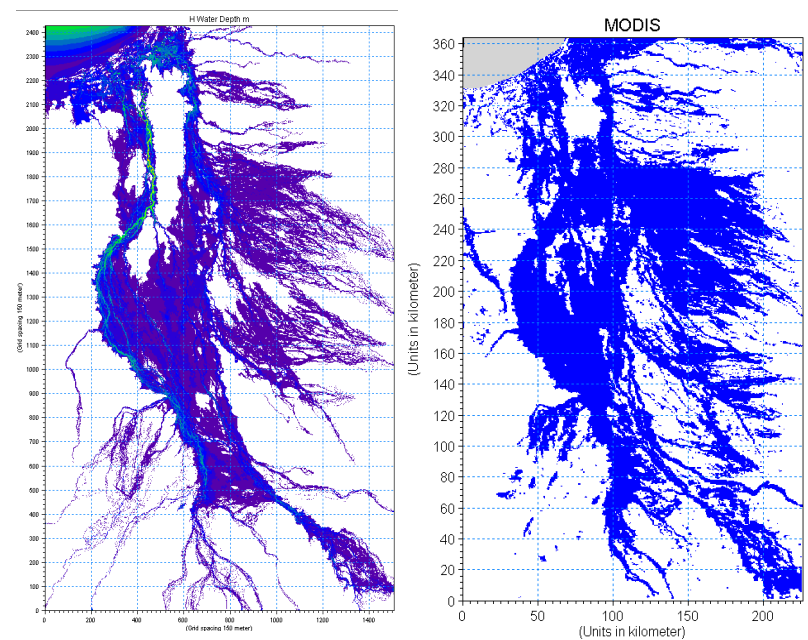

Figure 1. Comparison between model simulated and MODIS detected inundation on 15 Feb 2009. and MODIS detected results varies between 78 to $95 \%$ for total number of inundated cells and 44 to $72 \%$ for cell to cell comparison. Detail of HD model calibration can be found in Dutta et al. (2013).

Error! Reference source not found.Figure 3 presents the 6hourly time series of the number of inundated cells during the flood events of 2001 and 2009 under Cwet and Cdry scenarios. Under Scenario Cwet the maximum inundation area increased by 13 to $27 \%$ with an average of 14 to $23 \%$. Under
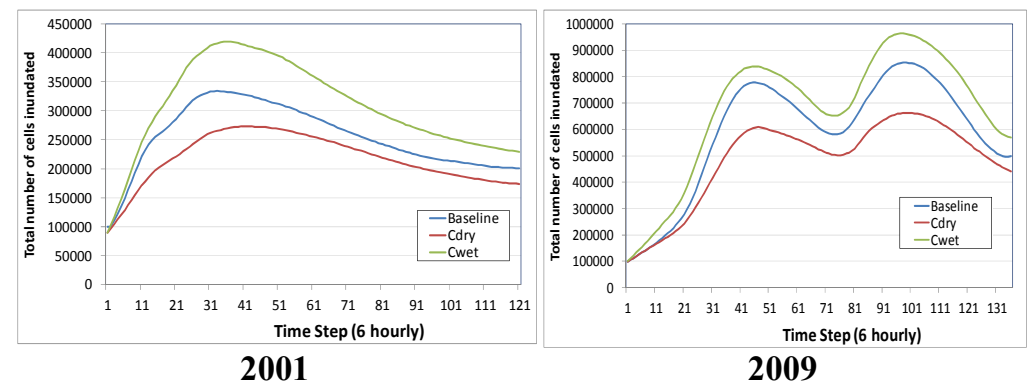

Figure 3. Time series of inundated cells for 2001 and 2009 events under Cwet and Cdry scenarios. 
Cdry, inundation area decreased by 18 to $22 \%$ at the maximum with an average of 15 to $18 \%$. The impacts of SLR on changes in floodplain inundation are less pronounced. Result shows projected SLR will cause only small increase in both inundation extent and depth. The reason is that much of the Flinders floodplain is above the tidal limit. The increase in the maximum area of inundation varies between 0.2 to $1.4 \%$.

Duration of inundation across the HD modelling domain was first calculated from the simulated results of the HD model and then time dynamics of simulated inundation information was used to assess connectivity between a wetland to its nearest major stream. Six hourly flood depth information derived from the two-dimensional HD model was used to calculate inundation duration. By accumulating this information for the entire simulation period total inundation duration for each computational grid cell was estimated. Figure 4 shows an example of inundation duration map for a large flood event in 2009 ( $2^{\text {nd }}$ largest in records). In general, duration of inundation is longer in the lower part of the floodplain. This is primarily due to the flat land topography in this region compared with the upper part of the floodplain. It also shows longer duration of inundation on both sides of the Flinders River. Large inflow from the upper catchments produced several kilometres of floodplain inundation across

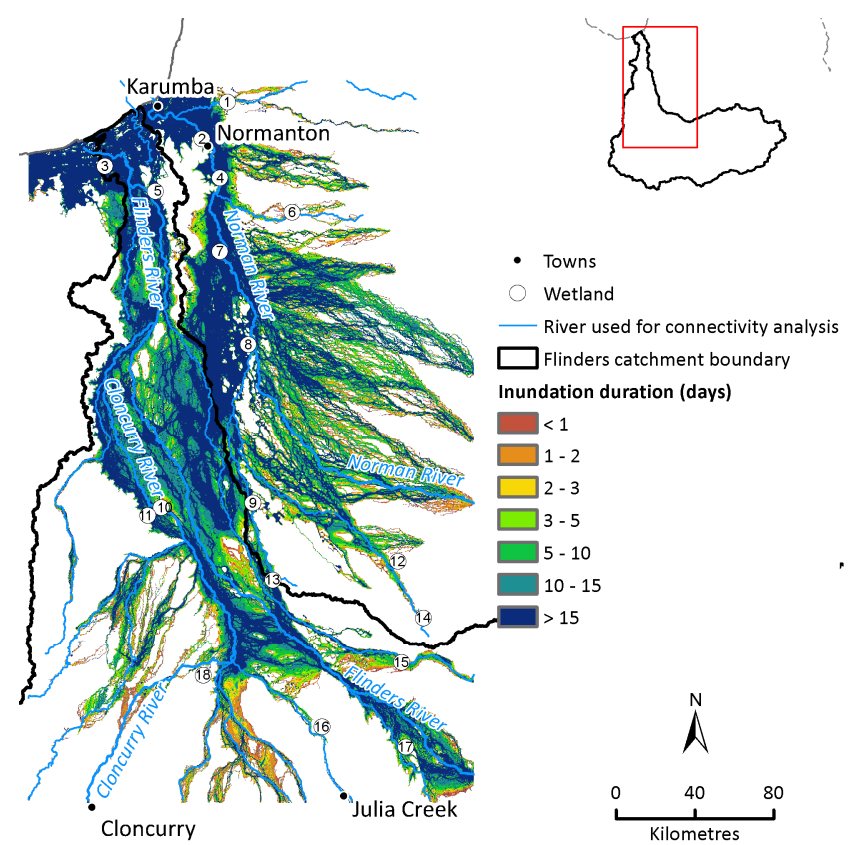

Figure 4. An example of spatial variation in inundation duration across the floodplain for the flood in 2009. the Flinders River on both banks. It is noticed that floodplains of Flinders and Norman merged together at the lower part of the catchments and produced relatively longer duration of inundation. The area and duration of inundation are small both for the Cloncurry River and Julia Creek at the upper part. This is mainly due to small catchment area above.

\subsection{Connectivity}

The results of connection timing and duration of connection of the wetlands to the rivers is shown in Figure 5 for the selected wetlands (ecologically important off-stream wetlands only) for 2001 and 2009 flood events. Four wetlands (e.g. Shady Lagoon, Burke \& Wills monument, 10 Mile Waterhole, Seaward Waterhole) showed continuous connection with streams during floods. These are large wetlands and located close proximity to rivers. For others, connectivity varies from 0 to 30 days depending on their location on the floodplain and the magnitude of flood. Flood event of 2009 (which is the second biggest flood in record) produced the highest duration of connectivity. As expected, large flood produced longer duration of connection. However local variation in runoff and inflow from upstream can produce different results as seen in Karim et al. (2012). This behaviour is

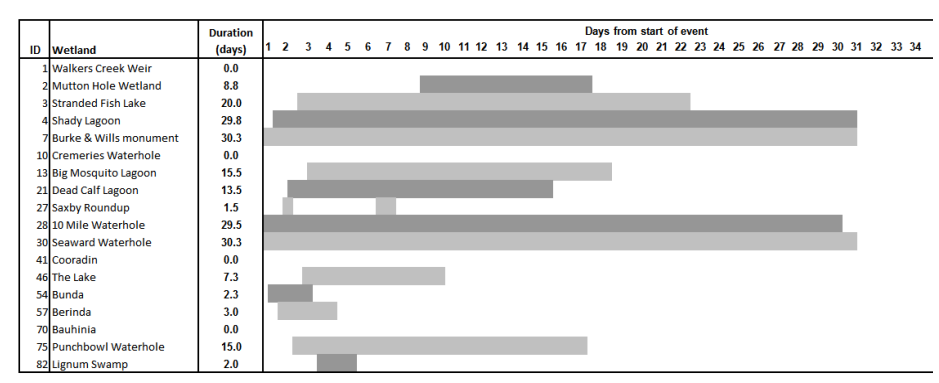

(a) Flood 2001

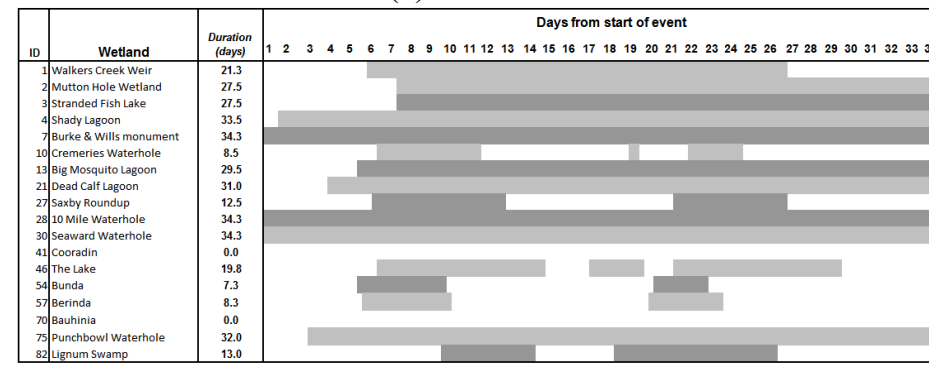

(b) Flood 2009

Figure 5. Timing and duration of connectivity of selected wetlands in the Flinders Catchment for (a) 2001 and (b) 2009 floods. 
being investigated using a different flood event (e.g. 2011).

The effects of climate change and future development on hydrological connectivity of floodplain wetlands were investigated. As expected wet climate increases the duration of connectivity and dry climate reduces the connectivity. The effect of climate change is significant for both wet $(\sim 10 \%)$ and dry $(\sim 20 \%)$ climate while the effect varies based on magnitude of flood. It is noticed that effect of climate change is disproportionate between wetlands. For example off-stream wetlands are more affected by climate change than on-stream wetland. The effect of SLR on connectivity is small and is limited to coastal wetlands only.

\section{CONCLUSIONS}

In this study, a two-dimensional HD model was calibrated to simulate floodplain inundation and connectivity between wetlands and main river channel. Connectivity status for a number of wetlands in the Flinders floodplain was quantified. Large flood produces longer duration of floodplain inundation and thus causes longer duration of wetland connectivity. Wetlands that are located lower part of the floodplain have the opportunity of longer duration of connection because of longer duration of inundation. It is also noticed that spatial variability in rainfall (and thus runoff) could influence the connectivity status of individual wetland. The study provides an overview of connectivity status and possible changes due to climate change and SLR to individual wetlands in the Flinders floodplain. The results reveals that connectivity will decrease under dry climate and increase under wet climate while impact of SLR is nominal. The information could be useful to future studies on movement and recruitment patterns of aquatic biota during floods, wetland habitat characteristics and water quality, and biodiversity of individual wetlands. In its current form the HD model is based on a re-sampled $150 \mathrm{~m}$ DEM. The results may improve if a finer resolution DEM (e.g. 30m) is used.

\section{ACKNOWLEDGMENTS}

We would like to thank the Australian Government Department of Regional Australia and Queensland Government for funding this research. We acknowledge the DERM Queensland for providing stream flow and tide data. Contribution from Guy Byrne of CSIRO in preparing land use map is thankfully acknowledged.

\section{REFERENCES}

Dutta D, Karim F, Ticehurst C, Marvanek S and Petheram C (2013). Floodplain inundation mapping and modelling in the Flinders and Gilbert Catchments. A technical report to the Australian Government from the CSIRO Flinders and Gilbert Agricultural Resource Assessment, part of the North Queensland Irrigated Agriculture Strategy. CSIRO Water for a Healthy Country and Sustainable Agriculture flagships, Australia.

Environment Australia (2001). A directory of Important Wetlands in Australia, Third Edition, Environment Australia, Canberra.

Frazier, P. and Page, K. (2006). The effect of river regulation on floodplain wetland inundation, Murrumbidgee River, Australia, Marine and Freshwater Research, 57, 133-141.

Lerat J, Egan C, Kim S, Gooda M, Loy A, Shao Q and Petheram C (2013). Calibration river models for the Flinders and Gilbert catchments. A technical report to the Australian Government from the CSIRO Flinders and Gilbert Agricultural Resource Assessment, part of the North Queensland Irrigated Agriculture Strategy. CSIRO Water for a Healthy Country and Sustainable Agriculture flagships, Australia.

Junk, W.J., Bayley, P.B. and Sparks, R.E. (1989). The flood pulse concept in river-floodplain systems. Canadian Special Publication of Fisheries and Aquatic Sciences, 106, 110-127.

Karim, F., Henderson, A., Wallace, J., Arthington, A.H. and Pearson R.G. (2012). Modelling wetland connectivity during overbank flooding in a tropical floodplain in north Queensland, Australia, Hydrological Processes, 18:2710-2723.

Kennard, M.J. (ed) (2011). Priorities for identification and sustainable management of high conservation value aquatic ecosystems in northern Australia. Final Report for the Department of Sustainability, Environment, Water, Populations and Communities and the National Water Commission. Tropical Rivers and Coastal Knowledge (TRaCK) Commonwealth Environmental Research Facility, Charles Darwin University, Darwin.

Petheram C and Yang A (2013). Climatic data and their characterisation for hydrological and agricultural scenario modelling across the Flinders and Gilbert catchments. A technical report to the Australian Government from the CSIRO Flinders and Gilbert Agricultural Resource Assessment, part of the North Queensland Irrigated Agriculture Strategy. CSIRO Water for a Healthy Country and Sustainable Agriculture flagships, Australia.

Shaikh, M., Green, D. and Cross, H. (2001). A remote sensing approach to determine environmental flows for wetlands of the Lower Darling River, New South Wales, Australia. International Journal of Remote Sensing, 22:1737-1751. 